\title{
Quality Analysis of Briquettes based on Waterding with Variation of Pressure and Pellet Geometry to Water Content and Value of Calories
}

\author{
Lintang Pratama, Dwi Pangga*, Dwi Sabda Budi Prasetya \\ Physic Education Department, Universitas Pendidikan Mandalika, Indonesia \\ *Corresponding Author Email: dwipangga@ikipmataram.ac.id
}

\begin{abstract}
Article History
Received: November 2020

Accepted: December 2020

Published: December 2020

\section{Key Words}

Water Hyacinth; Briquettes; Geometry;

Pressure
\end{abstract}

How to cite this article?

\begin{abstract}
This study is a research on water hyacinth-based briquettes which shows the calorific value of each form of briquettes. The purpose of this study was to analyze the quality of water hyacinth briquettes with variations in pressure and pellet geometry. The quality analyzed includes moisture content and calorific value. The method of making briquettes starts from charcoal, pounding, then mixing with tapioca starch adhesive. The composition of the mixture used is $90 \%$ water hyacinth charcoal with $10 \%$ tapioca starch adhesive. 4 geometric variations are used, namely, solid box, hollow box, solid tube and hollow tube with 3 pressure variations, namely, 10 PSI, 20 PSI and 30 PSI. Test results and analysis, briquettes at a pressure of 20 PSI produces a calorific value range of $91.15-150.14 \mathrm{cal} / \mathrm{gram}$. The resulting calorific value is higher than the briquettes at a pressure of 10 PSI and 30 PSI with a heating value range of $93.84-148.79 \mathrm{cal} / \mathrm{gram}$ and $89.81-135.39 \mathrm{cal}$ / gram. Hollow briquettes produce a calorific value range of 107.24 - 150.14 cal / gram higher than solid geometric briquettes which produce a heating value range of $89.81-148.79 \mathrm{cal} / \mathrm{gram}$. So that the contribution of the results of this research is that the community makes briquettes with shape and pressure with good results shown in this study.
\end{abstract}

Pratama, L., Pangga, D., \& Prasetya, D. (2020). Quality Analysis of Briquettes based on Waterding with Variation of Pressure and Pellet Geometry to Water Content and Value of Calories. Lensa: Jurnal Kependidikan Fisika, 8(2), 55-62. doi:https://doi.org/10.33394/j-1kf.v8i2.2758

\section{INTRODUCTION}

The level of demand for fuel energy sources is increasing from year to year. Various solutions and innovations have been made by scientists to overcome dependence on nonrenewable energy sources (Husada, 2008). Among them, the use of biobriquette as a fuel is one of the alternatives to save on the use of fossil fuels so that it can reduce the impact of carbon emissions (Saputata et al., 2013).

Coal and organic waste such as rice husks, coconut shells, and corn cobs are the main ingredients in making briquettes. In the last few years, many plants that grow in the waters have accumulated on the surface, causing blockage of water flow, one of which is the water hyacinth plant. Water hyacinth contains a lot of cellulose up to $64.51 \%$. The high content of cellulose is one of the advantages of water hyacinth so that it can be used to make briquettes.

Water hyacinth (Eichhornia Crassipes) is a type of floating aquatic plant with a very fast growth, so this plant is considered a weed that damages the aquatic environment. Water hyacinth is a water problem which until now has not been handled optimally. Some water gutters, DAMs, reservoirs, and the like have experienced silting, one of which is caused by water hyacinth.

Many dams in Indonesia suffer from silting due to the growth of water hyacinth which is difficult to control. Likewise with the Batujai Dam, which is the largest dam in 
Lombok, located in Central Lombok, every year dredging is carried out using heavy equipment, but two months later the growth of water hyacinth returns to its previous level. Various studies to maximize the use of water hyacinth so that it becomes something useful continue to be encouraged to improve its prospects and benefits.

Based on this very promising prospect, researchers in the last 3 years have struggled a lot in the process of processing water hyacinth into useful products, including Sugianto, et al. (2018) and Pangga, et al (2017 and 2018) succeeded in developing lightweight bricks made from water hyacinth. Likewise, Pangga \& Ahzan (2019) succeeded in making briquettes from water hyacinth with variations in the type and composition of the adhesive.

From the above ideas, the researcher continues the research results of Pangga \& Ahzan (2019) with the development of treatments on variations in pressure and geometry of briquette pellets. The development is to improve the quality of the briquettes in terms of moisture content and the resulting calorific value. One of the ways of this research will be to produce briquettes that can be used as a substitute for wood fuel to be applied as fuel for paving tobacco.

\section{METHOD}

This research is experimental research. The stages or methods of manufacture are as in Figure 1 below.

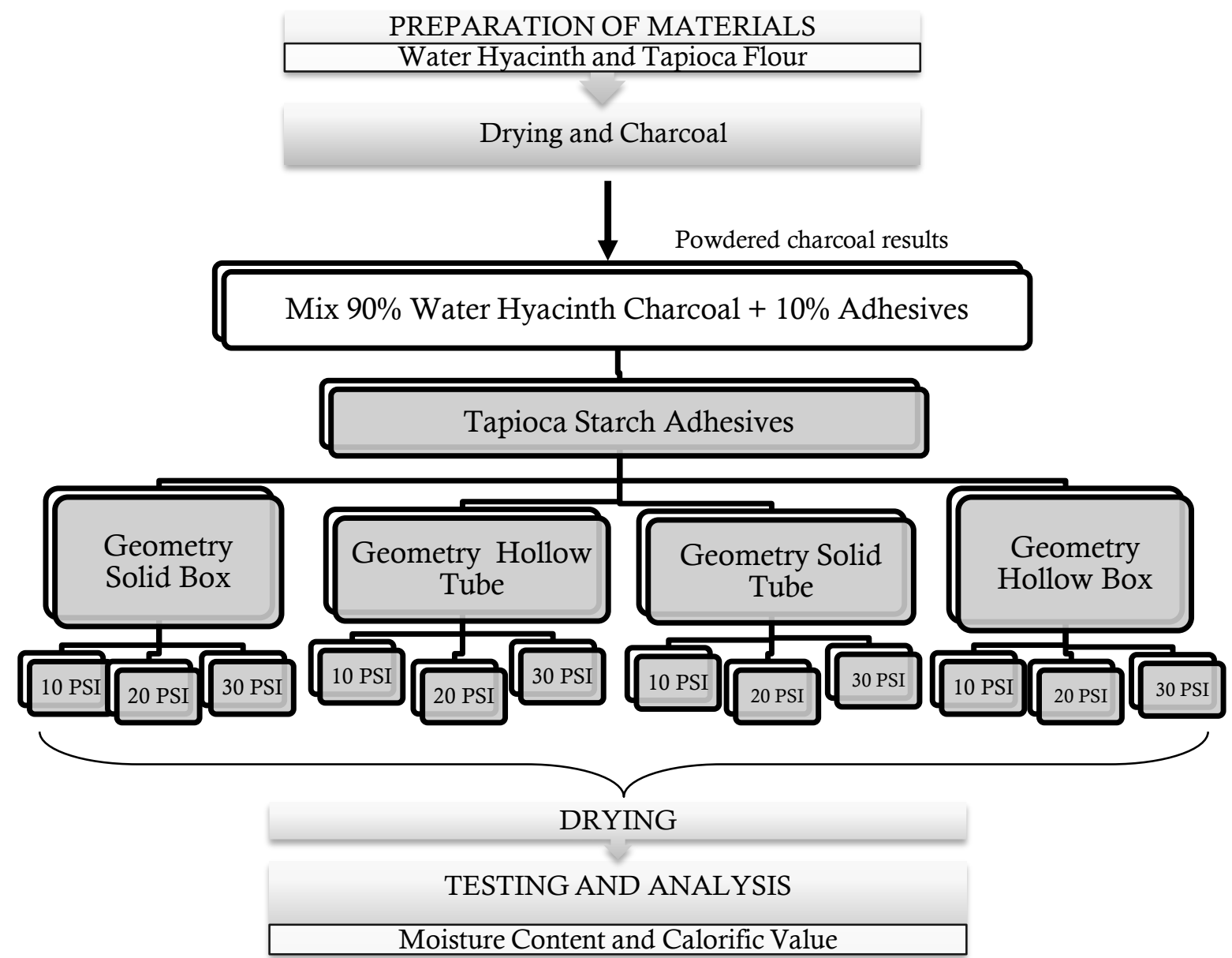

Figure 1. Research flow diagram

\section{Processing of materials into charcoal}

Water hyacinth is cleaned from dirt and mud by washing it with clean water. The clean water hyacinth is dried in the sun for 6 days and turned it every 4 hours so that it is 
evenly exposed to the sun. Once dry, then roasted like coffee until it turns black until it becomes charcoal. Then crushed until smooth, as shown in Figure 2.

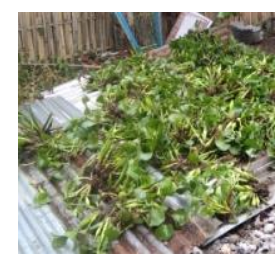

a

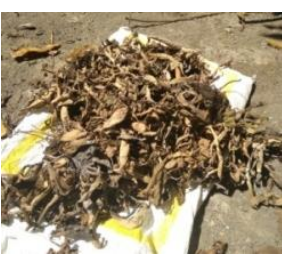

b

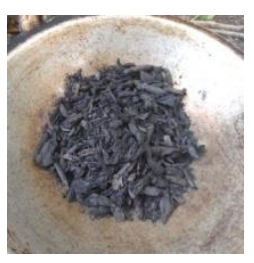

C

Figure 2. Water hyacinth in a) fresh condition b) dry c) charcoal

\section{The Process of Mixing Charcoal with Adhesives}

The mashed charcoal is then added with the adhesive that has been prepared in a ratio of $90 \%$ water hyacinth charcoal to $10 \%$ tapioca starch adhesive. Stir the glue and charcoal until everything is evenly mixed.

\section{Printing Process}

After stirring evenly, the dough is put into a briquette mold which consists of solid box geometry, hollow box, solid tube, and hollow tube. Then the pressure for each shape is given with a pressure variation of 10 PSI, 20 PSI, and 30 PSI.

\section{Testing Process}

\section{Water content}

The briquettes that had been printed were weighed in the initial mass (m1) and then put in an oven at $105^{\circ} \mathrm{C}$ for 1 hour. The briquettes were removed from the oven and allowed to cool and then weighed again (m2). The percentage of water content is calculated using the following equation:

$$
\text { Percentage of Water Content }=\frac{(m 1-m 2)}{m 1} \times 100 \%
$$

\section{Calorific Value}

Calorific value is measured by observing changes in temperature $(\Delta T)$ by using a test instrument in the form of water 200 grams (m) heated with briquette fuel which is ignited for 10 minutes. The test results are then entered into the following equation:

$$
\text { Calorific value }(\mathrm{Q})=m c \Delta T
$$

\section{RESULTS AND DISCUSSION}

Water hyacinth (Eichhornia Crassipes) is a type of floating aquatic plant. Water hyacinth has a very fast growth and is difficult to control so that it becomes a weed that damages the aquatic environment. In addition to its very fast growth, abundant presence, and not optimal utilization, water hyacinth also contains many elements of carbon, especially cellulose (C6H05) $\mathrm{n}$ (as in Tables 1 and 2.), so it is very suitable to be used as briquettes. (Pangga \& Ahzan, 2019).

Table 1. Elemental content of fresh water hyacinth plants

\begin{tabular}{cc}
\hline Chemical compound & Percentage (\%) \\
\hline Water & 92.6 \\
Ash & 0.44 \\
Crude fiber & 2.09 \\
Carbohydrate & 0.17 \\
Fat & 0.35 \\
Protein & 0.16
\end{tabular}




\begin{tabular}{cc}
\hline Chemical compound & Percentage (\%) \\
\hline Phosphorus as P2O5 & 0.52 \\
Potassium as K2O & 0.42 \\
Chloride & 0.26 \\
Alkanoids & 2.22 \\
\hline
\end{tabular}

Source: Moeksin, Comeriorensi, and Damayanti (2016).

Table 2. Content of elements / compounds of dried water hyacinth plants

\begin{tabular}{lcc}
\hline & Chemical compound & Percentage (\%) \\
\hline Cellulose & 64.51 \\
Pentosa & 15.61 \\
Lignin & 7.69 \\
Silica & 5,56 \\
Ash & 6.63 \\
\hline
\end{tabular}

Source: Fachri (2010)

The results of research and literature review show that making water hyacinth briquettes is feasible to continue to be developed. Article Fatmawati, (2015)shows a study on the potential utilization of organic waste biomass as an alternative fuel (briquettes). The briquettes tested used variations in the composition of water hyacinth and leaf ingredients. The ratio of water hyacinth and leaves applied was $1: 1 ; 2: 3 ; 3: 2 ; 1: 4 ;$ and $4: 1$. From this research, it was found that the highest calorific value was in the ratio of water hyacinth and leaves of 1: 4 with a calorific value of $4,348 \mathrm{cal} / \mathrm{gram}$. This shows that water hyacinth has the potential to be used as biobriquette as an alternative fuel.

Pellet geometry is the shape of a briquette in the form of a pellet. This geometry gives shape to the briquette and the briquette kiln with the size adjusted to the actual situation. The greater air velocity provides a greater oxygen supply as well (Mardwianta, 2009). In line with the above statement, Mallika Thabuot et al (2015) stated that hollow briquettes have oxygen flow space, thereforeburning will be easier. Briquettes are made with variations in pellet geometry and pressure as in Table 3 below.

Table 3. Geometry Variations \& Briquette Making Pressure

\begin{tabular}{|c|c|c|c|c|c|c|}
\hline \multirow{2}{*}{ No. } & \multirow{2}{*}{$\begin{array}{c}\text { Geometry } \\
\text { Types }\end{array}$} & \multirow{2}{*}{ Picture } & \multirow{2}{*}{ Composition } & \multicolumn{3}{|c|}{ Pressure (PSI) } \\
\hline & & & & 10 & 20 & 30 \\
\hline 1 & Solid Box & & & $\sqrt{ }$ & $\sqrt{ }$ & $\sqrt{ }$ \\
\hline 2 & Hollow Box & & $\begin{array}{c}90 \% \text { water } \\
\text { hyacinth charcoal } \\
+10 \% \text { tapioca } \\
\text { starch adhesive }\end{array}$ & $\sqrt{ }$ & $\sqrt{ }$ & $\sqrt{ }$ \\
\hline 3 & Solid Tube & & & $\sqrt{ }$ & $\sqrt{ }$ & $\sqrt{ }$ \\
\hline
\end{tabular}




\begin{tabular}{|c|c|c|c|c|c|c|}
\hline \multirow{2}{*}{ No. } & \multirow{2}{*}{$\begin{array}{c}\text { Geometry } \\
\text { Types }\end{array}$} & \multirow{2}{*}{ Picture } & \multirow{2}{*}{ Composition } & \multicolumn{3}{|c|}{ Pressure (PSI) } \\
\hline & & & & 10 & 20 & 30 \\
\hline 4 & Hollow Tube & & & $\sqrt{ }$ & $\sqrt{ }$ & $\sqrt{ }$ \\
\hline
\end{tabular}

In the process of drying the briquettes there is a reduction in mass because the newly minted briquettes still contain a lot of water, so they need to be dried so as not to disturb the calorific value. To determine the moisture content of a solid fuel, drying using sunlight and an electric oven can be done. Afif, et al. (2014). The test results and analysis of the briquette moisture content are shown in Table 4.

Table 4. Value of briquette moisture content

\begin{tabular}{clcccccc}
\multirow{2}{*}{ No } & \multirow{2}{*}{ Geometry } & \multicolumn{3}{c}{ Water content (gram) } & \multicolumn{3}{c}{ Percentage of Water Content } \\
\cline { 2 - 7 } & & 10 PSI & 20 PSI & 30 PSI & 10 PSI & 20 PSI & 30 PSI \\
\hline 1 & Solid Box & 4.42 & 4.99 & 4.99 & 6.72 & 7,19 & 7,20 \\
2 & Hollow Box & 4.62 & 5,10 & 4.57 & 6.96 & 7.66 & 6.91 \\
3 & Solid Tube & 3.87 & 3.68 & 4.52 & 6.85 & 6.19 & 7.43 \\
4 & Hollow Tube & 4.48 & 4.47 & 4.07 & 7.89 & 7.84 & 7.07 \\
\hline
\end{tabular}

Table 5. Standard values of briquette properties

\begin{tabular}{lcccc}
\hline \multicolumn{1}{c}{ Properties of Briquettes } & Japan & English & USA & SNI \\
\hline Water content (\%) & $6-8$ & $3-4$ & 6 & 8 \\
Volatile content & $15-30$ & 16 & 19 & 15 \\
Ash content (\%) & $2-6$ & $8-10$ & 18 & $8-10$ \\
Fixed carbon content (\%) & $60-80$ & 75 & 58 & 76 \\
Compressive Strength (kg / cm2) & 60 & 12.2 & 62 & 50 \\
Calorific value (cal / g) & $6,000-7,000$ & 7,300 & 6,500 & 5.60 \\
\hline
\end{tabular}

Sources: Balong, Isa, \& Iyabu (2016).

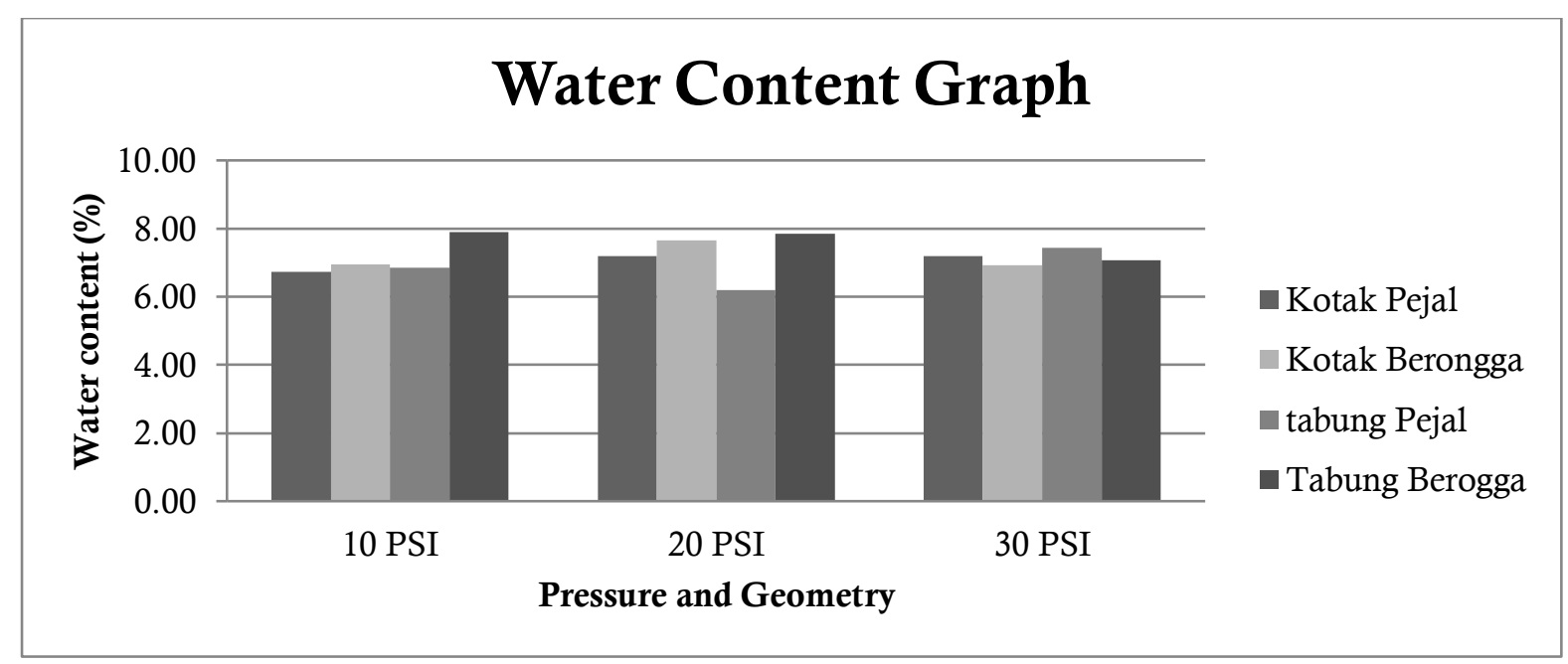

Figure 3. Graph of the Relationship between Pressure and Geometry on Water Content 
Based on Table 4, it can be seen that the briquettes that have the highest moisture content are briquettes with Hollow Tube geometry with a pressure of 10 PSI with a percentage of water content of $7.89 \%$. Meanwhile, the briquettes with the lowest water content were briquettes with Solid Tube geometry with a pressure of 20 PSI with a percentage of $6.19 \%$ moisture content. The moisture content of all samples ranged from $6.19 \%-7.89 \%$, so that based on Table 5 . it can be categorized into the standard value of the properties of briquettes. The factor that may cause differences in the percentage of water content in each briquette sample is due to the effect of the uneven mixture of starch, water, and water hyacinth charcoal on the briquette mixture (Iis, Sarwono, \& Ridho, 2009). In addition, the height of water cadres shown in hollow briquettes is compared to solid geometry briquettes. both in hollow boxes and hollow tubes, due to heating / oven heating, the heat distribution is more even in the hollow shape, causing a lot of water to evaporate when heating. This situation will cause the burning of briquettes in a hollow form to potentially produce a higher heat than in solid form, as can be seen from the resulting heat trend in table 6.

Table 6. Values of heat test results on briquettes.

\begin{tabular}{clccc}
\hline \multirow{2}{*}{ No. } & \multicolumn{1}{c}{ Geometry } & Calorific Value (J) \\
\cline { 3 - 5 } & & 10 PSI & 20 PSI & 30 PSI \\
\hline 1 & Solid Box & 10203.1 & 6250.6 & 9283.9 \\
2 & Hollow Box & 8364.7 & 10295.0 & 9192.0 \\
3 & Solid Tube & 6434.4 & 9192.0 & 6158.6 \\
4 & Hollow Tube & 7353.6 & 7561.2 & 9192.0 \\
\hline
\end{tabular}

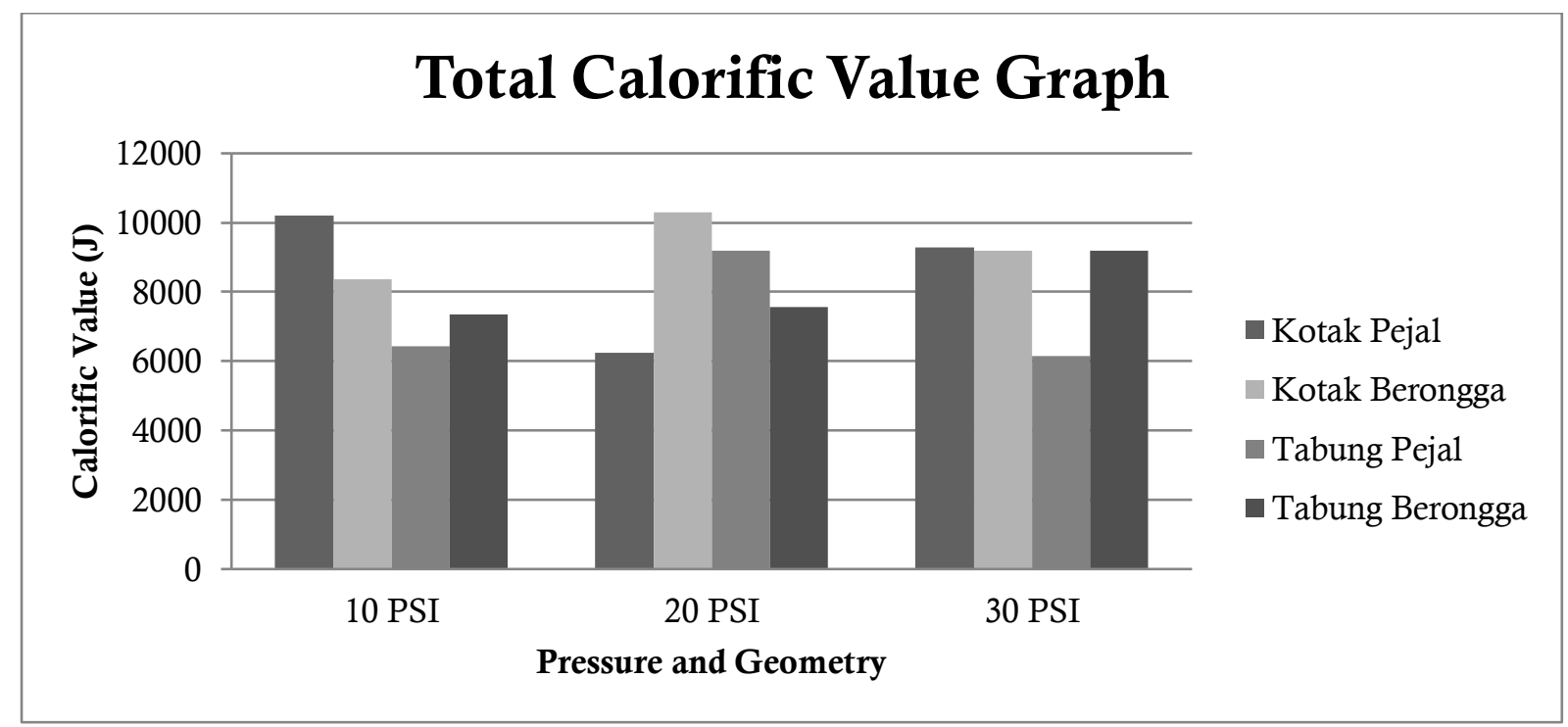

Figure 4. Graph of the Relationship between Pressure and Geomithy and Total Calorific Value

Based on Figure 4, the highest heating value is $10295.0 \mathrm{~J}$ with a Hollow Box geometry with a pressure of 20 PSI. While the lowest total calorific value is6158.6 J with Solid Tube geometry with a pressure of 30 PSI. This value is obtained within 10 minutes of the initial burning of the briquettes, so it cannot refer to the standard values for the properties of the briquettes used. This happened becauseHollow briquettes have a wider oxygen flow space, therefore combustion occurs more easily (Thabuot et al. 2015). The 
best pressure is 20 PSI because the elements of the briquette material are not too dense and not too tenuous.

\section{CONSLUSSION}

From the research that has been done it can be concluded that (1) briquettes with a pressure of 20 PSI produced a calorific value range of 91.15 - $150.14 \mathrm{cal} /$ gram higher than briquettes with a pressure of 10 PSI and 30 PSI with a heating value range of 93.84$148.79 \mathrm{cal} /$ gram and 89.81-135, $39 \mathrm{cal} /$ gram; and (2) hollow briquettes produce a calorific value range of $107.24-150.14 \mathrm{cal} /$ gram higher than solid geometric briquettes which produce a heating value range of $89.81-148.79 \mathrm{cal} /$ gram.

\section{RECOMMENTATION}

To produce more accurate heat data, combustion in subsequent studies was carried out using several briquettes and burning until it reached the maximum temperature without limiting the combustion time span.

\section{ACKNOWLEDGMENTS}

The author's gratitude goes to the Physics Laboratory and Chemistry Laboratory of the Undikma FSTT, who have helped and facilitated this research. We also express our gratitude to LPPM Undikma for funding support, and all parties who have helped the research process.

\section{REFERENCES}

Balong, S., Isa, I., \& Iyabu, H. (2016). Karakterisasi Biobriket dari Eceng Gondok (Eichornia Crassipes) sebagai Bahan Bakar Alternatif. Jambura Journal of Educational Chemistry, 11(2), 147-152.

Fachry R. dkk. (2010). Mencari Suhu Optimal Proses Karbonisasi dan Pengaruh Campuran Batubara terhadap Kualitas Briket Eceng Gondok. Jurnal Teknik Kimia, No. 2, Vol. 17, April 2010.

Fatmawati, D. (2015). Pembuatan Biobriket dari Campuran Enceng Gondok dan Tempurung Kelapa dengan Perekat Tetes Tebu. Jurnal Teknik Mesin, 3(02).

Husada, T.I. (2008).Arang Briket Tongkol Jagung sebagai Energi Alternatif, Laporan Hasil PenelitianProgram Inovasi Mahasiswa Provinsi Jawa Tengah. Universitas Negeri Surakarta, Semarang.

Iis, R., Sarwono, \& Ridho, H. (2009). Studi Eksperimental Karakteristik Briket Organik Bahan Baku Dari Twa Gunung Baung.

M. Afif Almu, Syahrul, Yesung Allo Padang. (2014). Analisa Nilai Kalor dan Laju Pembakaran Pada Briket Campuran Biji Nyamplung (Calophyllm Inophyllum) dan Abu Sekam Padi. Mataram. Dinamika tekhnik mesin.

Mardwianta, Benedictus. (2009). Laju Pembakaran Briket Batubara Berbentuk Silinder dengan Variasi Kecepatan Aliran Udara Pembakaran.Jurnal Angkasa Vol. 3 Mei 2011. Yogyakarta.

Moeksin, R., Comeriorensi, L., \& Damayanti, R. (2016). Pembuatan Bioetanol dari Eceng Gondok (Eichhornia Crassipes) dengan Perlakuan Fermentasi. Jurnal Teknik Kimia, 22(1), 1-9.

Pangga D., Hidayatullah, M.S., Sabda, D. (2017).Pembuatan Batako Ringan dari Limbah Pengolahan Emas dengan Filler Eceng Gondok. "Epistimologi Perkembangan Kurikulum Pendidikan di Indonesia dan Implementasinya”. ISBN: 978-602-61335-1-2 (211-219) 
Pangga, D \& Ahzan, S. (2019). Pengembangan Eceng Gondok sebagai Bahan Dasar Pembuatan Briket Sumber Energi Alternatif. Makalah disajikan dalam Seminar Nasional, FPMIPA IKIP Mataram, Mataram, 24 Agustus

Sugianto, I., Prasetya, D. S. B., \& Ahzan, S. (2018). Penggunaan Eceng Gondok Sebagai Filler untuk Meningkatkan Kuat Mekanik Batako Ringan Berbahan Dasar Limbah Emas. Lensa: Jurnal Kependidikan Fisika, 6(2), 43-49.

Supatata, N., Buates, J., \& Hariyanont, P. (2013). Characterization of fuel briquettes made from sewage sludge mixed with water hyacinth and sewage sludge mixed with sedge. International Journal of Environmental Science and Development, 4(2), 179.

Thabuot, M., Pagketanang, T., Panyacharoen, K., Mongkut, P., \& Wongwicha, P. (2015). Effect of applied pressure and binder proportion on the fuel properties of holey biobriquettes. Energy Procedia, 79, 890-895. 